\section{Ethnobotanical value of dry, fallen ovaries of Bombax ceiba $L$. (Bombacaceae: Malvales)}

\section{S. Gopakumar ${ }^{1} \&$ R. Yesoda Bai ${ }^{2}$}

${ }^{1}$ Department of Forest Management and Utilisation, College of Forestry, Kerala Agricultural University, Thrissur District, Kerala 680656, India

${ }^{2}$ Indian Forest Service, Indira Gandhi National Forest Academy, Dehradun, Uttarakhand 248006, India

Email: ${ }^{1}$ gopankau@gmail.com (corresponding author),

2yesodabai181@gmail.com

Indigenous people and their knowledge about nature and natural products have foremost importance in conservation efforts (Anderson \& Putz 2002; Ramakrishnan et al. 2005; Rist et al. 2008). Every community, especially ethnic ones, has strong linkages with plants and the possibility of uncovering new information from these relationships still remain enormous. Ethnobotany which explores human-plant interactions (Pei et al. 2009) is now more important than ever before. Numerous non-timber forest products (NTFPs) have ethnobotanical values on account of their medicinal, food and cultural significance. New uses connected with NTFPs are also being reported and getting documented for posterity. NTFPs constitute an important economic and natural resource, and are used for both family consumption and commercial trade (Kim et al. 2008). They also meet social needs

Date of publication (online): 26 December 2012

Date of publication (print): 26 December 2012

ISSN $0974-7907$ (online) | 0974-7893 (print)

Editor: Kannan C.S. Warrier

Manuscript details:

Ms \# 02936

Received 03 September 2011

Final received 12 October 2012

Finally accepted 14 October 2012

Citation: Gopakumar, S. \& R.Y. Bai (2012). Ethnobotanical value of dry, fallen ovaries of Bombax ceiba L. (Bombacaceae: Malvales). Journal of Threatened Taxa 4(15): 3443-3446.

Copyright: ( S. Gopakumar \& R. Yesoda Bai 2012. Creative Commons Attribution 3.0 Unported License. JoTT allows unrestricted use of this article in any medium for non-profit purposes, reproduction and distribution by providing adequate credit to the authors and the source of publication.

Acknowledgements: The authors wish to thank Mr. K.V. George and Mr. Chacko, local herbal dealers of Thrissur district, Kerala state, India for sharing information on the utilization aspects of dried ovaries.

\section{OPEN ACCESS | FREE DOWNLOAD (C) (i) ৫)}

(Griffiths etal.2003) and contribute significantly to the livelihood of rural residents (Angelsen \&

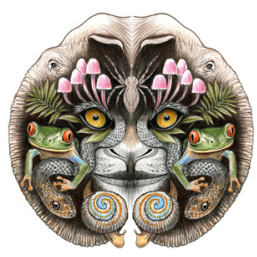
Wunder 2003; Sunderlin et al. 2005). About $80 \%$ of the population of developing countries use NTFPs to meet some of their health and nutritional needs (Beer \& McDermott 1996). In many of the thickly populated tropical regions, poor people still collect a wide range of forest products to sustain and supplement their livelihoods and escape hunger and poverty. However, information on such collection efforts and utilization aspects remains unaccounted largely due to the scattered nature of such efforts.

\section{Bombax ceiba and its ethnobotanical significance}

Bombax ceiba L., (Bombacaceae: Malvales), a tall deciduous tree with distinctive woody thorns on the trunk and branches (Brock 2001) is found in India, Australia (Liddle et al. 1994), Papua New Guinea, South-east Asia, China and the Indonesian Archipelago (Wightman \& Andrew 1989). This very common tree produces large crimson coloured flowers (Image 1) which are ornithophilous (Bhattacharya \& Mandal 2000). The flowers have a hard perianth with stiff filaments and a well protected ovary. The large, showy flowers usually appear when the trees are leafless.

There are many recorded ethnobotanical uses of $B$. ceiba. The Garo ethnic community of Tangail District of Bangladesh not only worships it, but also uses the paste of its bark to heal wounds. They also

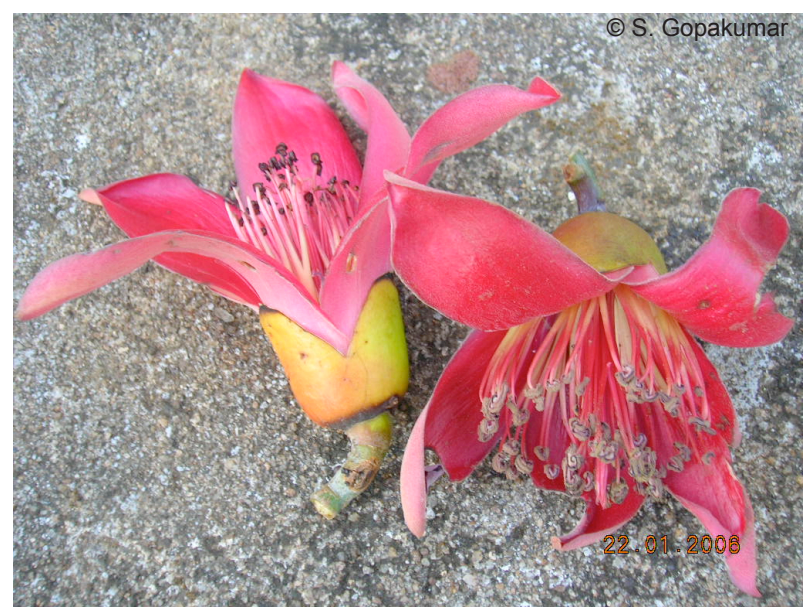

Image 1. Flowers of Bombax ceiba 
use a decoction of its root along with some other plant species as an aphrodisiac (Anisuzzaman et al. 2007). The timber is also used for making cheap furniture. The leaves of $B$. ceiba contain shamimin, a C-flavonol glucoside which has significant potency as a hypotensive agent (Saleem et al. 1999). The tree produces floss suitable for mattresses, cushions, pillows and quilts (Chand \& Singh 1999). The young leaves, petioles and seed cake (with very little or no gossypol) are used as excellent cattle feed. Aborigines in Australia use B. ceiba for making dugout canoes and for making twine. The tap roots of young plants of this tree species are used as food in Australia (Brock 2001).

A detailed account of the ethnobotanical uses of B. ceiba can be found in Jain et al. (2009). In India, many parts of this tree are being used for a variety of purposes. The Munda and Oraon tribes of northeastern India consume the flowers, calyx, and roots of young plants of B. ceiba (Jain 1996). The immature calyx known as "Semargulla" is consumed as a vegetable in Uttar Pradesh, in addition to the flowers and fleshy calyx (Jain 1996). As per the Council for Scientific and Industrial Research (CSIR 1988), the protein content, phosphorous and ether extract of the raw calyces compare favorably with those of common vegetables such as carrot, raddish, turnip, cabbage and pumpkin. A paste of its petals is mixed with breast milk and is applied externally to cure "red eyes" (Reddy et al. 2008). The young thorns are used as a substitute for betel nut. The root of $B$. ceiba is used as a tonic to heal waist pain (Srivastava 2007). The root tubers have high calcium content (Ghate et al. 1988). The gum oozing from young bark is edible (CSIR 1988). Gum extracted from older bark is used for book binding (Bose et al. 1998). During "Holika-dahan", a tribal festival, this tree is burnt down, though this practice severely jeopardizes its population in northern India (Jain et al. 2009).

\section{Materials and Methods}

In the main campus of Kerala Agricultural University in Thrissur District (10 $\left.30^{\prime} \mathrm{N} \& 76^{\circ} 15^{\prime} \mathrm{E}\right)$, Kerala State, India it was observed that some elderly women were regularly collecting fallen and dried ovaries (Image 2) from the base of standing B. ceiba trees. Based on one-to-one discussions with these women, we found that they were paid to collect and

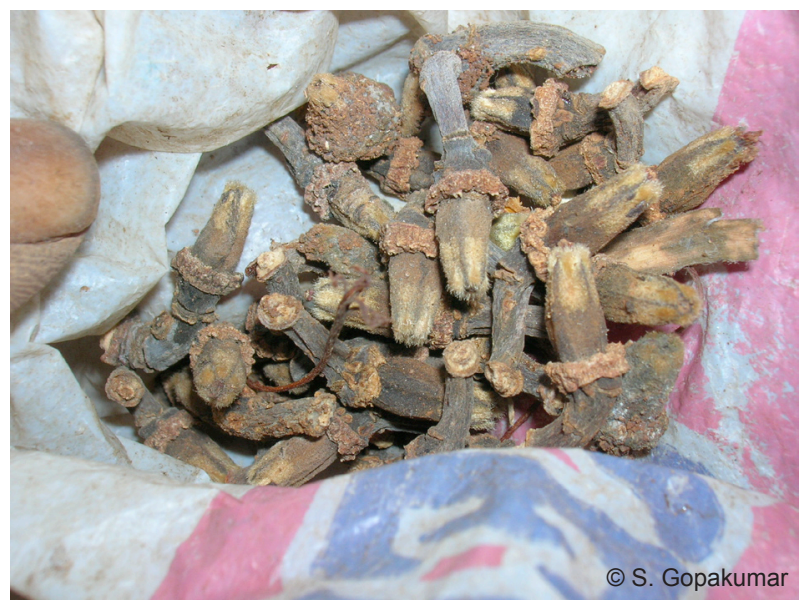

Image 2. A close view of dried ovaries

supply these ovaries to the herbal markets located in the nearby Thrissur Town. On further inquiry, the women also informed us that they are not aware of the actual use of these ovaries. The women just sell the collected ovaries in the nearby Thrissur herbal markets for one hundred Indian Rupees ( 1 US $\$=\sim 45$ Indian Rupees as on 03.12.2010) per kilogram. To know the exact use of the ovary, with the help of these women, we identified two key contact persons from among the local herbal dealers in Thrissur Town. We also interviewed 12 other herbal dealers on the actual use of these fallen Bombax ceiba ovaries. Information regarding the utilization of the ovaries was generated through personal interviews with these herbalists.

\section{Results and Discussion}

The interviewed herbal dealers informed us that these ovaries are in great demand in nearby Andhra Pradesh and Tamil Nadu states. There it is reportedly used in 'biryani' (traditional Indian spicy rice dish prepared using 'Basmati' rice mixed with meat, fish or vegetables) preparations. In the biryani, these dry ovaries will stabilize the cow's ghee. The Thrissur herbalists employ the local women for collecting and delivering the ovaries to their shops. Once the item is received, the women get paid depending on the stock they supply. Except for random cleaning by winnowing, the collected ovaries as such are sold to the customers who come asking for it. The herbal traders reported that the ovaries are also sought after by the commercial cattle feed manufactures located in Thrissur District for use in cattle feeds.

The calyces, flower petals and dried stamens of $B$. 
ceiba contain a rich array of chemicals (CSIR 1988; Jain et al. 2009). Dried and powdered flowers of this species are made into bread with or without corn. According to CSIR (1988), the B. ceiba flowers are made into a conserve by boiling it along with the seeds of poppy and sugar in goat's milk. Some bird species, squirrels and monkeys eat floral parts or whole flowers (Raju et al. 2005). However, the use of the fallen, dried ovaries in culinary preparations like 'biryani' and in commercial animal feed manufacture is a new report.

\section{Conclusions}

Of late, our scientists, natural resource managers and policy makers are increasingly recognizing the nonwood values of forests, including the socio-economic and cultural importance of NTFPs. The Planning Commission in its Approach to the $12^{\text {th }}$ Plan has also solicited suggestions to help organize markets, build infrastructure, capacity and upgrade skill for carrying out trade in NTFPs. The ethnobotanical information on NTFPs available in our country still remains to be documented. Since the dry, fallen ovaries of a multipurpose tree like Bombax ceiba is now observed to be used for a specific culinary purpose and is also used in cattle feed preparation, a detailed biochemical analysis will conclusively establish this additional ethnobotanical potential of this tree. If the nutritive value is established, the scope of farming this common tree species by employing tree improvement strategies will gain more significance. The confirmation of its nutritive value will also set the record straight in the issues related to its intellectual property rights. Concurrently, the collection and trade of the dried ovaries of $B$. ceiba will provide our rural populace an additional opportunity to supplement their livelihoods and reduce poverty.

\section{REFERENCES}

Anderson, P.J. \& F.E. Putz (2002). Harvesting and conservation: are both possible for the palm, Iriartea deltoidea? Forest Ecology and Management 170(1-3): 271-283.

Angelsen, A. \& S. Wunder (2003). Exploring the forest property link: key concepts, issues and research implications. Center for International Forestry Research Occasional Paper, Vol. 40. Bogor, Indonesia.

Anisuzzaman, M., A.H.M.M. Rahman, M. Harun-OrRashid, A.T.M. Naderuzzaman \& A.K.M.R. Islam
(2007). An ethnobotanical study of Madhupur, Tangail. Journal of Applied Sciences Research 3(7): 519-530.

Beer, J.H.D. \& M.J. McDermott (1996). The Economic Value of Non-timber Forest Products in South East Asia-2nd Revised Edition. The Netherlands Committee for IUCN, Amsterdam, 197pp.

Bhattacharya, A. \& S. Mandal (2000). Pollination biology in Bombax ceiba Linn. Current Science 79(12): 1706-1712.

Bose, T.K., P. Das \& G.G. Maiti (1998). Trees of the WorldVolume I. Regional Plant Resource Centre, Orissa, India, $89 \mathrm{pp}$.

Brock, J. (2001). Top End Native Plants - A Comprehensive Guide to The Trees and Shrubs of The Top End of The Northern Territory, Australia. Reed New Holland, Darwin, Australia, 354pp.

Chand, S. \& S.K. Singh (1999). In vitro Propagation of Bombax ceiba L. (Silkcotton). Silvae Genetica 48(6): 313-317.

CSIR (1988). Wealth of India-Volume 2: B. Raw Materials. Council for Scientific and Industrial Research, New Delhi, 176-185pp.

Ghate, V.S., V.V. Agte \& V.D. Vartak (1988). Promising economic potential of shemul (Bombax ceiba L.) as a tuber crop. Indian Journal of Forestry 11(2): 158-159.

Griffiths, A.D., A. Philips \& C. Godjuwa (2003). Harvest of Bombax ceiba for the aboriginal arts industry, central Arnhem Land, Australia. Biological Conservation 113(2): 295-305.

Jain, S.K. (1996). Glimpses of Indian Ethnobotany. Oxford \& IBH Publishing Co. New Delhi, Bombay, Calcutta, 365pp.

Jain, V., S.K. Verma \& S.S. Katewa (2009). Myths, traditions and fate of multipurpose Bombax ceiba L.- An appraisal. Indian Journal of Traditional Knowledge 8(4): 638-644.

Kim, S., N. Sasaki \& M. Koike (2008). Assessment of nontimber forest products in Phnom Kok community forest, Cambodia. Asia Europe Journal 6(2): 345-354.

Liddle, D.T., R.J. Smith, J. Brock, G.J. Leach \& G.T. Connors (1994). Atlas of The Vascular Rainforest Plants of the Northern Territory, Flora of Australia Supplementary Series Number 3. Australian Biological Resources Study, Canberra, 180pp.

Pei, S., Z. Guoxue \& H. Huyin (2009). Application of traditional knowledge in forest management: Ethnobotanical indicators of sustainable forest use. Forest Ecology and Management 257(10): 2017-2021.

Raju, A.J.S., S.P. Rao \& K. Rangaiah (2005). Pollination by bats and birds in the obligate outcrosser Bombax ceiba L. (Bombacaceae), a tropical dry season flowering tree species in the Eastern Ghats forests of India. Ornithological Science 4(1): 81-87.

Ramakrishnan, P.S., R. Boojh, K.G. Saxena, U.M. Chandrashekara, D. Depommier, S. Patnaik, O.P. Toky, A.K. Gangawar \& R. Gangwar (2005). One Sun, Two Worlds: An Ecological Journey. UNESCO and Oxford \& IBH, New Delhi, 286pp.

Reddy, K.N., C.S. Reddy \& V.S. Raju (2008). Ethnomedicinal observations among the Kondareddis of Khammam 
District, Andhra Pradesh, India. Ethnobotanical Leaflets 12: 916-26.

Rist, L., R.U. Shaanker, E.J.M. Gulland J. \& Ghazoul (2008). Managing mistletoes: the value of local practices for a non-timber forest resource. Forest Ecology and Management 255: 1684-1691.

Saleem, R., M.Ahmad, S.A. Hussain, A.M. Qazi, S.I. Ahmad, M.H. Qazi, M. Ali, S. Faizi, S. Akhtar \& S.N. Husnain (1999). Hypotensive, Hypoglycaemic and Toxicological Studies on the Flavonol C-Glycoside Shamimin from Bombax ceiba. Planta Medica 65(4): 331-334.
Srivastava, K. (2007). Ethnobotanical studies of some important ferns. Ethnobotanical Leaflets 11: 164-172.

Sunderlin, W.D., A. Angelsen, B. Belcher, P. Burgers, R. Nasi, R. Santoso \& S. Wunder (2005). Livelihoods, forests and conservation in developing countries: an overview. World Development 33: 1383-1402.

Wightman, G.M. \& M. Andrew (1989). Plants of the Northern Territory Monsoon Vine forests. Conservation Commission of the Northern Territory, Darwin, Australia, 163pp. 